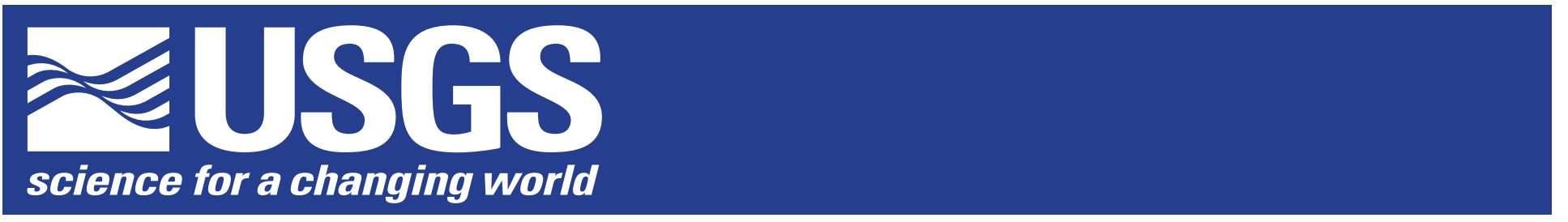

U.S. Department of the Interior

U.S. Geological Survey

\title{
U.S. GEOLOGICAL SURVEY REAL-TIME RIVER DATA APPLICATIONS
}

\section{The U.S. Geological Survey (USGS) is a primary source of real-time data for flood warnings and forecasts. River flood warnings and forecasts are key elements in protecting lives and property.}

In the United States, flooding has

-caused the deaths of more than 10,000 persons since 1900,

-produced damages averaging $\$ 3.1$ billion annually in the last 10 years, and

-been a major factor in 9 out of 10 presidential disaster declarations.

Indiana is not immune to the effects of flooding. Some examples of damaging floods that have occurred in Indiana include

\section{-1982 flooding in Fort Wayne that caused} $\$ 50$ million in damages,

-1991 flooding in much of Indiana that caused more than $\$ 100$ million in damages, and

-flooding along the Ohio River in 1997 that resulted in more than $\$ 7.5$ million in damages.

\section{STREAMFLOW-GAGING STATIONS}

Real-time river data provided by the USGS originate from streamflow-gaging stations. The USGS operates and maintains a network of more than 7,000 such stations across the nation (Mason and Wieger, 1995). These gaging stations, used to produce records of stage and streamflow data, are operated in cooperation with local, state, and other federal agencies. The USGS office in Indianapolis operates a statewide network of more than 170 gaging stations.

The instrumentation at USGS gaging stations monitors and records river information, primarily river stage (fig. 1). As technological advances are made, many USGS gaging stations are being retrofitted with electronic instrumentation to monitor and record river data. Electronic instrumentation facilitates transmission of real-time or near real-time river data for use by government agencies in such flood-related tasks as operating flood-control structures and ordering evacuations.

\section{DATA TELEMETRY}

The primary communication system used by the USGS for data transmission is earth-satellite telemetry. More than 4,000 USGS gaging stations across the nation have satellite-telemetry capability (Mason and Wieger, 1995). All 48 of the USGS satellite telemetry-equipped gaging stations in Indiana transmit data on a regular 4-hour interval. The data travel through several satellites and ground stations to USGS offices. Indiana has begun to configure gagingstation instruments that will, in addition to transmitting on fixed intervals, transmit if a pre-set river stage or changein-stage threshold is exceeded.

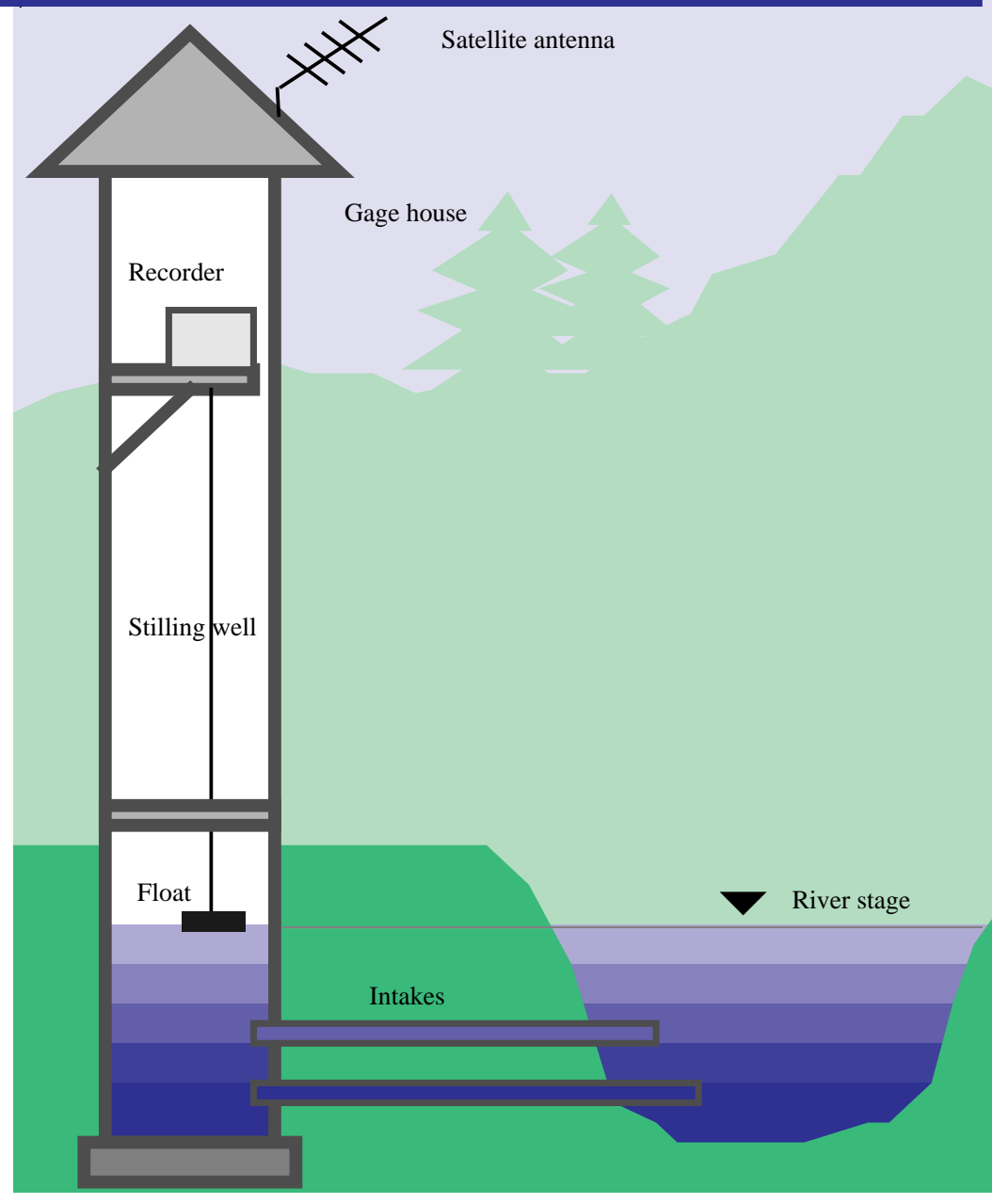

Figure 1. Sketch of a U.S. Geological Survey streamflowgaging station.

The USGS also uses land-line telephone telemetry. In Indiana, about 50 gaging stations are equipped to transmit data by landline telephone. Currently, the USGS office in Indianapolis calls these gaging stations once daily and downloads data onto a computer. Land-line telephone gaging-station instrumentation can be programmed to call and transmit data to USGS offices or to cooperating agencies whenever a pre-set river stage or change-in-stage threshold is exceeded.

Cellular-telephone telemetry is a third method of river-data telemetry employed by the USGS. In 1995, the USGS Indiana District established a real-time data network to monitor rainfall and river stage in the Little Calumet River Basin in northwestern Indiana. The network is operated in cooperation with the U.S. Army Corps of Engineers as part of a flood-protection project for the Little Calumet River Basin. This network transmits stream-level and rainfall data from 11 USGS gaging stations. 


\section{ACCESS TO AND USE OF REAL-TIME RIVER DATA}

Most of the data transmitted by satellite telemetry are received by the National Weather Service river-forecast centers where personnel use the data to prepare flood forecasts and warnings. The forecasts and warnings then are distributed to local forecasting offices that distribute the information to the public. The forecasts and warnings allow federal, state, and local officials to take early actions, such as evacuations and road closures.

To further facilitate use of real-time river data by the general public, the USGS began providing real-time river data through the World Wide Web (fig. 2). The Indiana District's web page began offering real-time river data in June 1996. Since then, the Indiana District web page has served thousands of real-time river hydrographs. Real-time data give emergencymanagement officials the ability to make decisions during floods and allow citizens to make decisions regarding their lives and property.

Gaging stations in the Little Calumet River cellulartelephone network transmit data directly to computers at local emergency-management offices where personnel can make rapid decisions concerning evacuations and road closures. Data also are transmitted to the Indiana USGS office in Indianapolis where the operational status of the gaging stations is monitored.

\section{BENEFITS}

Across the nation, benefits from the availability of realtime data for flood warnings are becoming more apparent. Examples include

-the 1995-96 winter floods in Oregon, when realtime data provided by the USGS was used by federal, state, and local agencies to manage the storage and release of flood waters upstream from Portland, thereby reducing potential property losses by $\$ 2.7$ billion (U.S. Geological Survey, 1996);

-the extensive 1993 Midwest floods, during which the National Weather Service relied on USGS real-time data to issue more than 135 flood warnings and more than 2,500 river flood statements (Mason and Wieger, 1995).

Benefits from real-time data availability also have been realized in Indiana, such as

-the decision by Lake County emergency managers to cancel a major road closure based on data provided by the Little Calumet River Basin network, which saved personnel hours and costs that would have been incurred by the closure of an important thoroughfare;

- flood warnings and forecasts provided by the National Weather Service during the 1997 flooding along the Ohio River that allowed local officials to take early action in issuing evacuation notices.

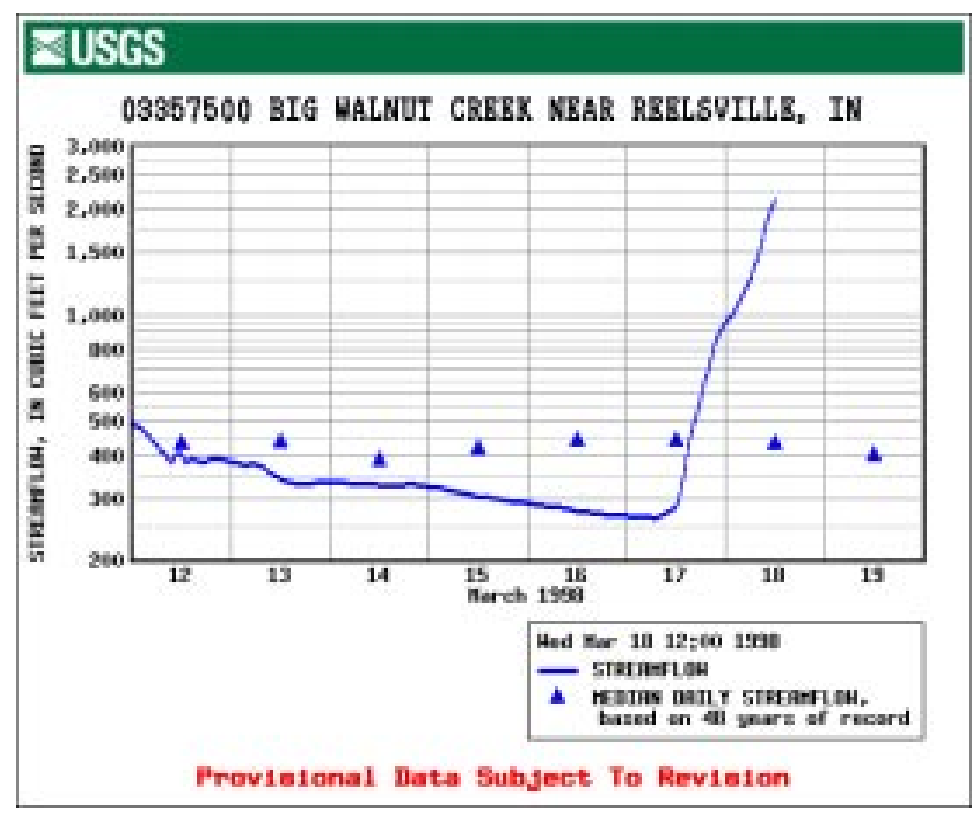

Figure 2. Example of real-time hydrograph from U.S. Geological Survey World Wide Web page.

\section{FUTURE OPPORTUNITIES}

The demand for real-time data is likely to increase. In addition to flood warnings and forecasts, many other uses for real-time data exist-such as reservoir management, water-withdrawal operations, waste-disposal management, and recreational activities.

New technologies in data collection, telemetry, and presentation continue to emerge. Many of these technologies undoubtedly will be used by the USGS to meet the growing need for real-time data.

-Scott E. Morlock

\section{SELECTED REFERENCES}

Mason, R.R. and Wieger, B.A., 1995, Stream gaging and flood forecasting - A partnership of the U.S. Geological Survey and the National Weather Service: U.S. Geological Survey Fact Sheet FS-209-95, 4 p.

U.S. Army Corps of Engineers, 1995, Annual flood damage report to Congress for Fiscal Year 1995, table 1.

U.S. Federal Emergency Management Agency, 1991, Interagency hazard mitigation report for Indiana, disaster declaration FEMA-885-DR-IN: Chicago, Ill., 36 p.

U.S. Federal Emergency Management Agency World Wide Web site, http://www.fema.gov

U.S. Geological Survey, 1996, The U.S. Geological SurveyRecent program highlights: U.S. Geological Survey Fact Sheet FS-113-96, 2 p.

\section{For more information, contact District Chief \\ U.S. Geological Survey 5957 Lakeside Boulevard Indianapolis, IN 46278 http://in.water.usgs.gov/}

Additional earth science information can be found by accessing the USGS Home Page on the World Wide Web at http://www.usgs.gov 